\title{
COR RESPONDENCE.
}

\section{The Cross and Solomon's Seal as Indian Emblems.}

SrR,-In Captain Conder's very valuable work on " Heth and Moab" (London, 1883), I find it urged, as an argument against Mr. Fergusson's identification of certain rude stone crosses as Christian monuments, "that the cross in India is found as a sacred emblem amongst Buddbists and Brahmins alike from a very early period. Nothing," adds Captain Conder, "could be primâ facie more improbable than the erection of rude stone monuments by Christians in India" (p. 225). Is this argument founded on fact? In some years' study of Indian archæology I have not seen any instance of the use of a genuine cross as a sacred emblem by either Buddhists or Brahmins.

We have, indeed, the "Swastika" and its reverse form the "Varddhamana." But these might as well be called wheels or whirligigs as crosses; though they are certainly sacred emblems. Again we have several characters (especially one ancient numeral) in both ancient and modern Indian languages which might be called crosses. But these are by no means sacred; not even as the $X$ which we use in ' $X$ mas' is with us.

Similar forms occur occasionally in decoration, not only with Hindus and (perhaps) Buddhists, but among the nonBrahmanical forest tribes. But I cannot find that they are a bit more sacred or symbolical than any other conventional ornament ; say the Ionic Volute or the "Acanthus."

The crosses from which Mr. Fergusson argued (Rude Stone Monuments, p. 486 et seq.) are themselves monuments 
as much as any in Ireland or Scotland, and as complete. To me they seem to be as clearly Christian crosses as these; and I think that there is one thing primâ facie more improbable than their erection by Christians, videlicet, their erection by any one else.

Again, in the same work (p. 56), I find Captain Conder stating that "Solomon's seal" and "David's shield" (the 5 and 6-pointed stars formed by combinations of triangles) are "Indian caste-marks." What evidence is there of this? Setting aside the common error of calling those devices "caste-marks," which are used by Hindus to indicate sect, and not caste, $I$ think that there is a mistake in fact. I have never seen, nor heard of, the use of either of these patterns as a brow-mark or tattoo by any Hindus. And although they do occur as mason's marks in India, I think that they are confined to Musalman buildings, and are, in short, a comparatively modern imported luxury.

I should be glad if any member could give me any further light on either subject. Captain Conder, rather provokingly, quotes no authority, nor am I aware of his having any Indian experience such as would enable me to accept his own as conclusive.

In another passage he mentions the swastika as "a castemark amongst Vaishnavas." Setting apart, again, the incorrect term "caste-mark," and the more readily as the following term "Vaishnavas" implies some idea of the real use of the brow-marks, the thing seems likely enough. But where and who are those Vaishnavas who so use it?

W. F. Sinclair.

The Secretary of the Royal Asiatic Society.

2.

London, 1888.

Dear Mr. Rhys Davids,-Looking over your two little Buddhist books, the following notes occur; and, if new, may perhaps be worth putting on paper. In the animal-stories there are clearly two or three animals classed as " deer." 